\title{
Structural relationships among vegetation, soil fauna and humus form in a subalpine forest ecosystem: a Hierarchical Multiple Factor Analysis (HMFA)
}

\author{
Nicolas Bernier ${ }^{\mathrm{a}, *}$, François Gillet ${ }^{\mathrm{b}, \mathrm{c}}$ \\ a Muséum National d'Histoire Naturelle, Ecologie et Gestion de la Biodiversité, 4 Avenue du Petit-Château, 91800 Brunoy, France \\ b Université de Franche-Comté - CNRS, UMR 6249 Chrono-environnement, 16 route de Gray, 25030 Besançon Cedex, France \\ ${ }^{\mathrm{c}}$ Ecole Polytechnique Fédérale de Lausanne, Ecological Systems Laboratory, Station 2, 1015 Lausanne, Switzerland
}

\section{A R T I C L E I N F O}

\section{Article history:}

Received 27 January 2012

Received in revised form 29 June 2012

Accepted 30 June 2012

\section{Keywords:}

Humus form

HMFA

Soil fauna

Forest mosaic

Synusia

Plant-soil interactions

\begin{abstract}
A B S T R A C T
Aboveground vegetation, four belowground fauna groups and humus composition have been analyzed in order to investigate the links between autotrophic and heterotrophic communities in a Norwayspruce mountain forest in Tours-en-Savoie (France). The aboveground plant community was recorded in small patches corresponding to contrasting microhabitats. Animal communities and humus layers were sampled within the same patches. The relationships between humus profile, faunistic and floristic compositional gradients were investigated by Multiple Factor Analysis (MFA) and, for the first time in ecology, a Hierarchical Multiple Factor Analysis (HMFA) was used to interpret differences among humus layers. The analysis revealed a pattern with three main groups of microhabitats. The thorough study of separate humus layers could explain this result. The interplay of plant-animal-soil interactions is likely to drive the ecosystem toward three alternative states supporting humus traditional classification between mull-mor-moder. HMFA revealed the importance of depth to explain this contrast among humus forms, using humus layers as diagnostic tools in both inert and living components. HMFA also showed contrast between unexploited and exploited parts of the forest, but the study of soil and vegetation indicate that this contrast does not only hold in forest management but also in geomorphology. RV-coefficients among the six groups of variables showed significant fauna-fauna relationships in almost all humus layers except Actinedida. Plant-soil interactions are not as strong as expected and are even weaker when the soil in question is deep. In addition, HMFA failed to show direct interactions between plant and soil fauna but, paradoxically, HMFA does suggest that indirect plant-fauna interactions are at the focus of the ecosystem strategy that leads to the differentiation of ecological niches within the forest mosaic.
\end{abstract}

(c) 2012 Elsevier GmbH. All rights reserved.

\section{Introduction}

One of the main ecological challenges since the end of the last century has been to connect biodiversity with ecosystem processes such productivity (Kareiva 1994; Tilman et al. 1997), stability (Bardgett and Cook 1998), dynamics (Siemann et al. 1999; Marra and Edmonds 2005; Salmon et al. 2008), biogeochemical cycling (Beare et al. 1995), and forest regeneration (Nagaike et al. 1999). On the one hand, the soil food web is fundamental to plant growth (Wardle 1999). On the other, plant debris is essential in the organization of humus communities (Lavelle et al. 1993; Berg et al. 1998). Most studies have examined either the effect of plant diversity on soil processes (Spehn et al. 2000; Zimmer 2002) or the effect of soil biotic diversity on soil fertility and plant productivity (King et al. 2002; Scherer-Lorenzen et al. 2003) without having confirmed

\footnotetext{
* Corresponding author. Tel.: +33160479210.

E-mail address: bernier@mnhn.fr (N. Bernier).
}

any correlation between the diversity of the soil biota and plants (Hooper et al. 2000; Porazinska et al. 2003; Coleman and Whiteman 2005).

The purpose of this work is to search for some connections between soil fauna and plant communities, and to discern processes that explain these correlations, if any exist. Our working hypothesis was that variations in the local composition of plant communities will influence the soil fauna through differences in litter composition (Ball et al. 2009). In turn, the soil fauna will regulate humus processes by controlling the rate of litter decomposition, the nature and chemical activity of soil organic matter and thus, will influence the conditions for fine-scale vegetation structure and dynamics (De Deyn et al. 2003; Crow et al. 2009; Laganière et al. 2009; Mathieu et al. 2009). Humus composition is the meeting point of animal and plant communities: the long-lasting effect of humus properties is able to influence plant and animal community composition, which then again influence humus composition and properties. These feedback loops are supposed to result in a spatial segregation of closely linked communities and humus forms. 
This hypothesis will be tested by comparing a set of microhabitats within a single forest. One major concern in investigating relationships among biotic communities is the question of appropriate scale (Huston 1999; Loreau 2000). In our case, the vegetation has to be described at a scale of homogeneous units sufficiently small to allow soil fauna to discriminate (Tilman 2000; Mathieu et al. 2009; Doblas-Miranda et al. 2009). In forest ecosystems, the herb layer can be described as a mosaic of plant synusiae that are linked to contrasting microhabitats, indicating differences in edaphic and microclimatic conditions (Barkman 1978; Gillet and Gallandat 1996). Within the forest phytocoenosis, we can thus delimit multi-layered microcoenoses (Barkman 1978), each including a distinct herb synusia and the superposed vegetation layers (shrubs and trees). Given the small-scale organization of humus components, the scale of plant microcoenosis is still large for soil fauna but it represented the appropriate level of description to determine a shared structure between flora, fauna and humus compartments.

\section{Materials and methods}

\section{Study site}

The subalpine forest under study covers 15 ha in the Toursen-Savoie commune (western northern Alps, France: $45^{\circ} 40^{\prime} 40^{\prime \prime} \mathrm{N}$; $6^{\circ} 27^{\prime} 57^{\prime \prime} \mathrm{E}$ ). Altitude ranges between 1575 and $1750 \mathrm{~m}$ a.s.l., with a south-west facing aspect. The bedrock is a mixture of micaceous schists and albitic gneisses, the soil type is a Leptosol (IUSS Working Group 2006) and the vegetation belongs to Piceetum subalpinum myrtilletosum David 1979 according to traditional phytosociological classification. The total annual rainfall varies between 1200 and $1600 \mathrm{~mm}$ with half this amount falling in the form of snow.

The western part of the forest ( $8.5 \mathrm{ha})$ is more intensively and regularly exploited than the eastern part (6.5 ha). Thus we will call the western area E (exploited) and the eastern area $U$ (unmanaged). Both parts of the forest were described as high-altitude coniferous forests in 1729 according to land registry and map of the Sardinian kingdom (http://www.savoiearchives.fr/index.php?id=1233). From 1729 to 1891 , logging was frequent. The $U$ area was entirely clear-cut in 1830-35 (EynardNachet, personal communication). The $\mathrm{E}$ area was probably partially clear-cut during the same period. Landslides creating hollows crossing the slope and denuding little cliffs are common in the $U$ area but rare in the $E$ area. The slope of the $U$ area is consistently steep $\left(35^{\circ}\right)$ compared to E area $\left(20-30^{\circ}\right)$.

\section{Vegetation sampling}

To investigate the fine-scale plant-fauna-humus interactions we selected three phytocoenoses within the Tours-en-Savoie forest, with homogeneous conditions for tree-age structure, slope, and geomorphology.

Phytocoenosis E2 is under sylviculture regime. It shows contrasts between spruce-shaded Prenanthes purpurea and Oxalis acetosella synusia (microcoenosis E2-PO) and spruce-shaded Vaccinium myrtillus synusia (microcoenosis E2-PV). This phytocoenosis also exhibits a contrast between moist $O$. acetosella synusia shaded by maple (microcoenosis E2-AO), sunny dry, species-poor or species-rich $V$. myrtillus heath (microcoenoses E2-Vp and E2-Vr, respectively) and sunny moist microhabitats with Athyrium filixfemina and Rubus idaeus as dominant plant species (microcoenosis E2-R).

Phytocoenosis U8 developed under unmanaged conditions and shows a simple forest mosaic of tree and ericaceous heath elements (microcoenoses U8-P and U8-Vp, respectively).
Phytocoenosis U10 (unmanaged conditions) exhibits complex interactions between Luzula nivea synusia shaded by spruce (microcoenosis U10-PL), O. acetosella synusia shaded by maple (microcoenosis U10-AO) and sunny microhabitats dominated by Agrostis agrostiflora and $R$. idaeus (microcoenosis U10-AgR).

In a given phytocoenosis, each component of the forest mosaic (i.e., each microcoenosis) was sampled using a list of plant species with their cover ratio code according to Braun-Blanquet's 6-level dominance scale (classes $+, 1,2,3,4,5$, based on visual estimation of the percentage cover through all vegetation layers). The vegetation survey was carried out in a $20-\mathrm{m}^{2}$ area inside each of the 11 microcoenotic forest units during the 1999 summer season. The semi-quantitative dominance code was replaced by the central percentage cover of the corresponding class for further statistical analyses.

Ecological preferences of plant species with respect to $\mathrm{pH}$, soil water and light were recorded according to a 3-level scale. For example: a strict acidophilic species was reported as acidophilic $=2$ and basophilic $=0$; a plant species more frequent in acidic condition is quoted as acidophilic $=2$ and basophilic $=1$. The plant database was taken from Aeschimann et al. (2004). In a given forest microcoenosis, the mean ecological preference of the plant species, weighted by dominance, provides an ecological indicator of microhabitat condition.

\section{Humus profile and soil fauna}

The eleven microcoenotic forest units were sampled for humus layers and soil fauna. Humus layer sampling followed the microstratified method of Ponge (1984) and Bernier and Ponge (1994). First, a column of undisturbed humus material, with an area of $25 \mathrm{~cm}^{2}$ and a maximum depth of $15 \mathrm{~cm}$, was isolated from the surroundings by progressively excavating the material around it using a sharp knife, scissors and pruning shears. Second, humus layers were separated manually with scissors from top to bottom; the humus layers were immediately fixed in $95 \%$ (v/v) ethyl alcohol. We measured the depth of each layer with an accuracy of $0.5 \mathrm{~cm}$ and a short, visual description was done. The sampling process was complete once the bedrock was reached given that Leptosols were very shallow. Humus composition was estimated at $40 \times$ magnification under a dissecting microscope using a seven-level ordinal scale. Each eleven humus profile showed layers with different thickness. For statistical reasons, 4 depth limits were chosen $(1,2,3$ and $5 \mathrm{~cm}$ below surface) regardless of layer composition. As a consequence, reference to the nature of layer was only considered a posteriori for interpretation needs. Humus typology follows Baize et al. (2009).

Soil animals were separated by hand under the dissecting microscope within the same humus material. It was often necessary to dissect plant fragments and humus aggregates that could possibly enclose animals. Among the fauna, only Nematodes and Protozoa were not counted given their small size and transparency. All specimens were identified to species for springtails (Collembola), to genera for Oribatid mites, to family for Actinedida mites and to supra-family taxonomical levels for the rest of the fauna.

\section{Data analysis}

Multiple Factor Analysis (MFA) (Escofier and Pagès 1994) was used to link symmetrically six different groups of descriptors, that is the four soil fauna groups, flora and humus components, and a passive supplementary group of data (diversity indices, forest management and plant ecology). Moreover, Hierarchical Multiple Factor Analysis (HMFA) was used to explore interactions between habitats and depths (Le Dien and Pagès 2003).

Popular asymmetric constrained ordination methods, such as CCA (Canonical Correspondence Analysis) or RDA (Redundancy 
Analysis), were not applicable here since hypotheses were drawn on the relationship between soil fauna, flora and humus form without assuming a priori any causal relationship, and because the number of objects was very low compared to the number of descriptors in each group (Dray et al. 2003). Among the variety of symmetric ordination methods that are available for the linking of ecological data tables, MFA was chosen because it allows the simultaneous coupling of several groups or subsets of variables defined for the same objects (Escofier and Pagès 1994; Borcard et al. 2011). MFA is a simple variant of co-inertia analysis, which seeks the common structures present in all or some of these subsets. As this method, to date mainly used in sensory evaluation and chemistry, is not familiar to ecologists, we provide the following summary of its principles.

If all variables are numerical (as it is the case for all active data in our study), then MFA is basically a Principal Component Analysis (PCA) applied to the whole set of variables in which each subset is weighted. Qualitative variables may be used in MFA but need to weight the proportions between modalities. The use of weights balances inertia between the different groups and thus balances their influences. Each group of variables can get the status 'active' or 'passive': a passive (or illustrative) group does not contribute to the construction of axes.

MFA is performed in two steps. First, a PCA is performed on each subset, which is then normalized by dividing all of its elements by the first eigenvalue obtained from its PCA. Second, the normalized subsets are merged to form a unique matrix, which is subjected to a global PCA. The individual subsets are then projected onto the global analysis to analyze commonalities and discrepancies.

Various graphical displays are available for MFA: objects, variables, groups or PCA axes. The interpretation of objects (point position) and variables (arrow length and angle) is the same in PCA. In the superimposed display of objects, each object appears as a cloud of several points: one 'partial' point for each active group, which gives the position of the object from the point of view of this group, and one average point, which is the center of gravity of the partial ones.

The similarity between the geometrical representations derived from each group of variables is measured by the RV-coefficient, ranging from 0 to 1 (Robert and Escoufier 1976). RV-coefficients can be tested by permutations (Josse et al. 2008).

Prior to MFA, raw dominance or abundance of taxa and humus components were transformed by $\ln (y+1)$ to avoid placing too much importance to extreme values. Contrary to site profiles, species or double profiles commonly used in community ecology (Legendre and Gallagher 2001; Dray et al. 2003), this simple log-transformation does not remove important information about absence and relative quantities among objects or descriptors. For this reason, no standardization was applied to any subset of active variables in the MFA. However, quantitative and binary variables of the passive group were centered and scaled since they were not dimensionally homogeneous.

HMFA is a generalization of MFA integrating several hierarchical levels (Le Dien and Pagès 2003). This method is of high potential interest in ecology given the complexity of the systems under study.

All computations were performed with R 2.10.1 (R Development Core Team 2009) and the FactoMineR package (Lê et al. 2008; Husson et al. 2009).

\section{Results}

Plant and soil fauna communities

Plant species richness in the eleven studied microcoenoses ranged between 3 and 29 species (Appendix A).
We identified 28,608 animals from the eleven humus cores encompassing 116 taxa (Appendix B). The mean density was slightly more than $10^{6} \mathrm{~m}^{-2}$. The highest animal density was reached in the U8-P spruce unit $\left(3.6 \times 10^{6} \mathrm{~m}^{-2}\right)$ and the lowest in the U10-AO Acer/Oxalis unit $\left(0.4 \times 10^{6} \mathrm{~m}^{-2}\right)$. Oribatida were the most numerous fauna (56\%), followed by Collembola (14\%), Enchytraeidae (10\%), Actinedida (9\%) and Protura (3\%). We distinguished four soil fauna groups: Collembola, Oribatida mites, Actinedida mites and supra-family fauna taxa. They were considered independent active groups in MFA and HMFA since each describes a distinct and homogeneous taxonomical level (Appendix B).

\section{Humus composition}

We identified 41 humus components encompassing plant fragments (spruce, bilberry, moss, herb or fern litter remains), animal feces (organic or a mixture of organic and minerals) and soil material (Appendix C). Humus form varied from mor and dysmoder (abundance of both litter and holorganic feces) to mull (low litter abundance together with high content of earthworm organomineral feces).

\section{MFA}

We first performed five MFAs on separate humus layers and one MFA combining all layers, each with the six independent groups of variables including a total of 55 plant species, 37 supra-family fauna taxa, 37 Collembola species, 43 Oribatida mite genera or morphotypes, 33 Actinedida families or morphotypes and 41 humus components. Taxonomic richness and Shannon diversity of each community (using abundance for fauna and cover for plant species), forest regime and plant ecology were added as supplementary variables in a passive group. Variance associated with the three first axes of separate PCAs ranged from 75.2 to $79.7 \%$ for Collembola, 75.7 to $87.9 \%$ for Oribatida mites, 68 to $85.9 \%$ for Actinedida mites, 66.4 to $87.7 \%$ for supra-family fauna, 51.9 to $71.6 \%$ for humus components and 62 to $69.9 \%$ for the passive supplementary variables. The unique flora matrix used for the six MFAs showed a cumulative percentage of variance of $62.4 \%$. The three first axes of the six MFAs accounted for $54.4-59.2 \%$ of the total variance, with axis 1 alone accounting for $24.3-31.5 \%$.

$\mathrm{RV}$-coefficients among the six groups of variables (Table 1) ranged between 0.3 and 0.9 . Animal groups showed significant relationships with other groups in almost all humus layers except Actinedida notably in the top layer. In contrast flora showed only significant links with humus variables in the two uppermost layers. Humus descriptors were well correlated to Oribatida and supra-family fauna taxa, but to a lesser degree to Collembola and Actinedida.

The six MFAs were closely related (Table 2). Axis 1 of the four uppermost layers showed contrast between spruce and herb habitats, whereas heath habitats were often discriminated along axis 2. Contrast between the $\mathrm{E}$ and $\mathrm{U}$ part of the forest was evident for the whole humus profile (along axis 2) and for various depths: $0-1 \mathrm{~cm}$ (axis 4), 3-5 cm (axis 2) and below $5 \mathrm{~cm}$ (axis 2). In the six MFAs, E2$\mathrm{Vr}$ (species-rich Vaccinium vegetation) positioned itself between herb and heath habitats but closer to herb habitats, whereas E2-PV (Vaccinium habitat shaded by spruce) was closer to heath than to spruce habitats.

Passive data explained the contrast between spruce and herb habitats by both light and acidity levels as depicted by plant ecology (Appendix C). When focusing on plant species, MFA axis 1 showed a strong correlation with species richness and diversity (in the direction of the herb branch) (Appendix A). In contrast, spruce and heath branches were mainly correlated with Picea abies and $V$. myrtillus, respectively. Additional passive data indicated that heath branches 
Table 1

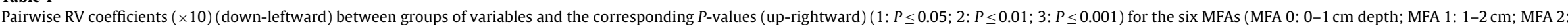
2-3 cm; MFA 3: 3-5 cm; MFA 5: > $5 \mathrm{~cm}$; MFA $t$ : total).

\begin{tabular}{|c|c|c|c|c|c|c|c|c|c|c|c|c|c|c|c|c|c|c|c|c|c|c|c|c|c|c|c|c|c|c|c|c|c|c|c|c|}
\hline \multirow[t]{2}{*}{ MFA } & \multicolumn{6}{|c|}{ Collembola } & \multicolumn{6}{|c|}{ Oribatida } & \multicolumn{6}{|c|}{ Actinedida } & \multicolumn{6}{|c|}{ Fauna } & \multicolumn{6}{|c|}{ Flora } & \multicolumn{6}{|c|}{ Humus } \\
\hline & 0 & 1 & 2 & 3 & 5 & $t$ & 0 & 1 & 2 & 3 & 5 & $t$ & 0 & 1 & 2 & 3 & 5 & $t$ & 0 & 1 & 2 & 3 & 5 & $t$ & 0 & 1 & 2 & 3 & 5 & $t$ & 0 & 1 & 2 & 3 & 5 & $t$ \\
\hline Collembola & & & & & & & 3 & 2 & 2 & 1 & & 2 & & & 3 & 1 & 1 & 2 & 3 & 3 & 3 & 2 & 1 & 3 & & & & & & & 1 & & 2 & 2 & 1 & 2 \\
\hline Oribatida & 7 & 7 & 8 & 6 & 5 & 7 & & & & & & & & & 1 & & 2 & 1 & 3 & 3 & 2 & 1 & 2 & 2 & & & & & & & 2 & 2 & 3 & 2 & 2 & 3 \\
\hline Actinedida & 3 & 5 & 8 & 6 & 7 & 8 & 3 & 5 & 6 & 4 & 6 & 6 & & & & & & & & 1 & 1 & 1 & 2 & 2 & & & & & & & & & 1 & & 1 & 2 \\
\hline Fauna & 7 & 7 & 7 & 7 & 6 & 8 & 9 & 9 & 7 & 6 & 6 & 7 & 4 & 5 & 7 & 7 & 8 & 7 & & & & & & & & & & & & & 2 & 3 & 1 & 1 & 2 & 3 \\
\hline Flora & 4 & 4 & 5 & 4 & 5 & 5 & 4 & 5 & 5 & 4 & 4 & 4 & 4 & 5 & 6 & 5 & 5 & 5 & 4 & 5 & 6 & 7 & 6 & 6 & & & & & & & 2 & 2 & & & & 2 \\
\hline Humus & 6 & 6 & 7 & 7 & 6 & 7 & 7 & 7 & 7 & 7 & 7 & 7 & 4 & 6 & 7 & 5 & 7 & 7 & 6 & 7 & 7 & 7 & 7 & 8 & 8 & 8 & 7 & 6 & 6 & 7 & & & & & & \\
\hline
\end{tabular}

Table 2

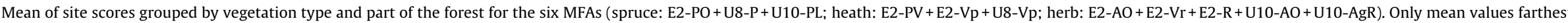
from the axis origin are shown.

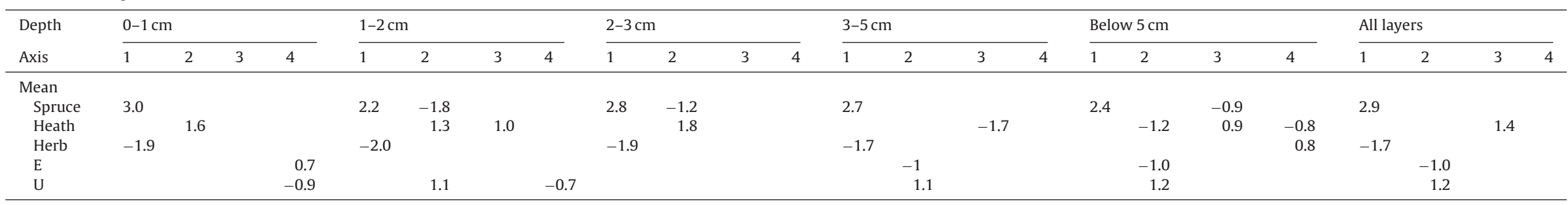


discriminate both dry and sunny conditions for these bilberry communities (Appendix C). Management (positive side of MFA axis 2) promotes a few heliophilous species such as V. myrtillus, Anthoxanthum odoratum, Knautia dipsacifolia, P. purpurea and Phyteuma betonicifolium. The unmanaged part of the forest promotes Agrostis schraderiana, A. filix-femina, Calamintha grandiflora, Dryopteris filixmas, Rosa pendulina and $R$. idaeus, which are known to be frequent in rock-slide and moist habitats (Aeschimann et al. 2004). Those preferences suggest that the difference between the $U$ and $E$ part of the forest not only holds for forest management but also fir geomorphology.

In contrast to what was observed with plant species, fauna dispersion along the three first MFA axes was not strongly unbalanced (Appendix B). Thirty-seven taxa among the 99 shown in Appendix $B$ were placed on the spruce side of axis 1, 14 taxa on the herb side of axis 1 and 20 taxa toward the heath branch of axis 3 . Those results could not be explained by the grouping of fauna abundance by main taxa, which was significantly higher in spruce habitat, but only in terms of richness and diversity. Spruce habitat only had higher Collembola richness whereas herb habitat had higher levels of Oribatida and supra-family fauna diversity. On the other hand, heath habitat (positive side of MFA axis 3 ) promoted Oribatida and Actinedida richness as well as Actinedida diversity.

\section{HMFA}

The similarity between the six MFAs justified the need to perform HMFA with two hierarchical levels. On the one hand, interactions within fauna groups and between fauna and humus components may be independent of depth but on the other hand, depth exerts an influence on every humus component. This asymmetry defined hierarchy. The upper level involved five sets of variables, one for each depth of belowground humus layers and one additional set for aboveground vegetation. The lower level consisted of the six groups of variables previously used for the six MFAs. The five depth-specific matrices (four for fauna and one for humus components) were used for the belowground data sets. The clouds of 352 dots ( 32 sets and groups $\times 11$ habitats) in the plane of HMFA axes 1 and 2 showed 3 elongation axes matching with spruce, herb and heath habitats (Fig. 1). The three first axes of HMFA accounted for $51.7 \%$ of the total variance, axis 1 alone accounting for $24.9 \%$, similar to MFA results. Discrepancies between vegetation and the barycentre were partially confirmed with the weak

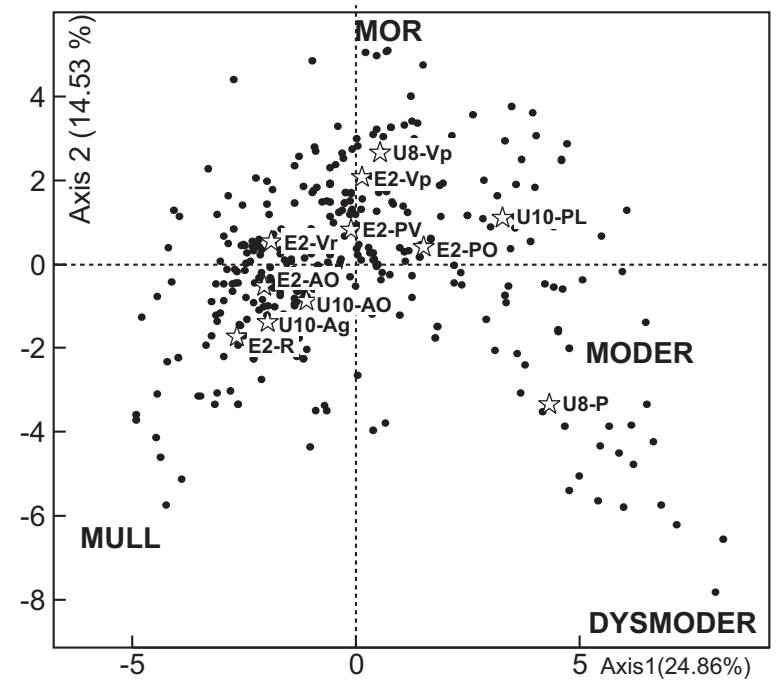

Fig. 1. Scatter plot of the 352 sampling points in the two first axes of HMFA for the 11 habitats.

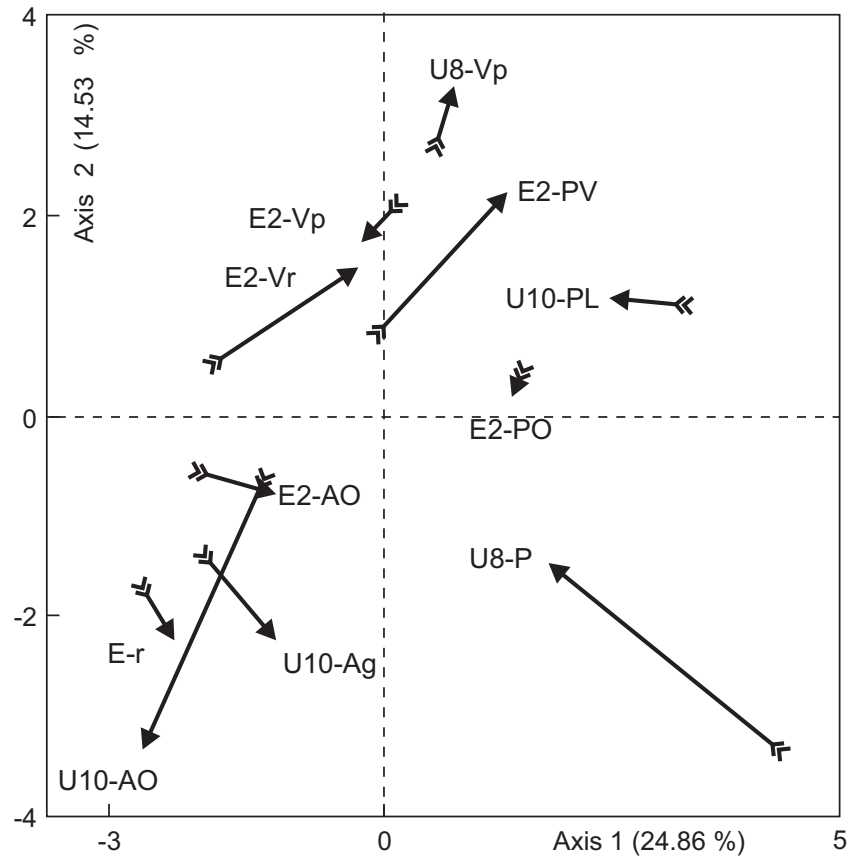

Fig. 2. Position of plant groups (arrow head) compared to the barycentre (arrow basis) for the 11 habitats in the two first axes of HMFA.

discrimination of U8-P and the high discrimination of E2-PV and U10-AO by vegetation data (Fig. 2). This result has to be reconciled with the low RV coefficients for vegetation in the six MFAs (Table 1).

The three spruce habitats showed three different interactions among fauna, humus composition and depth for the eleven habitats in the plane of HMFA axes 1 and 2; U8-P (pure spruce habitat, unexploited forest) was the furthest (Fig. 3). Every subset followed loops in the plane of axes 1 and 2 except Actinedida whose influence increased constantly with depth. Spruce direction was characterized by large amounts of leaf material and feces (Appendix C). For the U8-P habitat, these latter features were emphasized in both superficial and deep layers. This abundance of litter and feces in deep layers is consistent with the dysmoder humus form (Baize et al.2009). Oxalis shaded in the spruce habitat (E2-PO) also showed a significant but different interaction with depth (Fig. 3). Shallow layers were placed in the moder area of HMFA, but with increasing depth, habitats and animals converged progressively toward those found in mull side. This trend was repeated itself regardless of the animal subset. Thus, E2-PO consisted of a typical moder habitat near ground level, but a mull habitat with depth. This also happens to be the description of the amphimull humus form (Baize et al. 2009). Lastly, Luzula shaded by spruce (U10-PL) only showed a poor interaction with depth.

Heath habitats had a poor dispersion around the barycentre (i.e., a weak interaction with depth; data not shown). E2-Vr (heath habitat rich in plant species) was found considerably left of the barycentre near the herb position, which is in agreement with the six MFAs analysis. This humus form was the only one among ericaceous habitats to show interactions with depth, being similar to what was observed for heath at layers below $3 \mathrm{~cm}$ and for herbs at the ground-level layer. HMFA placed E2-PV (bilberry heath shaded by spruce) in the heath area, just slightly closer to origin along axis 2.

The Acer-Oxalis habitats showed poor dispersion around the barycentre, confirming the lack of interactions with depth (data not shown). In contrast, Rubus and Agrostis habitats showed interactions with depth. Fig. 4 suggests that despite plant discrimination 

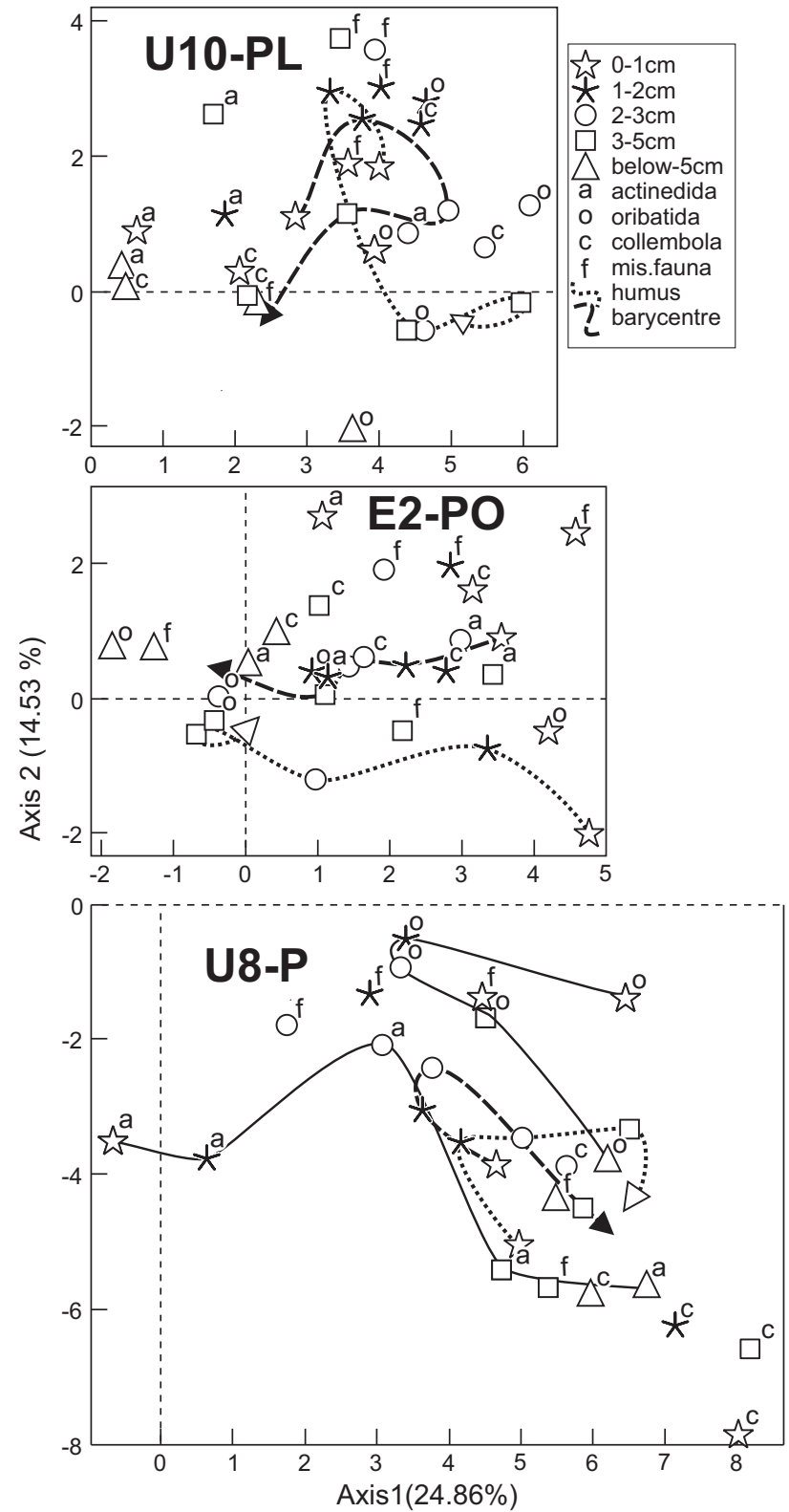

Fig. 3. Position of spruce habitats in the two first axes of HMFA according to depth and animal or humus groups.

(Fig. 2), Rubus and Agrostis habitats had the same humus characteristics. Near-ground-level samples were furthest in the herb direction and with increasing depth samples fell closer to the origin. Similarity between Rubus and Agrostis underground habitats was very high for Collembola and Oribatida even though the spreading around the barycentre was low for Collembola. For Actinedida and supra-family groups, similarity between the two habitats was high for the uppermost humus layers but weaker for deeper layers. This trend was also observed for humus composition but with depth the contrast was higher for U10-Ag than for E2-R.

As for several MFAs, the third HMFA axis showed contrast between unexploited and exploited parts of the forest (Fig. 5). For both humus and fauna, the contrast was higher on the herb side of axis 1 compared to the spruce side. Fig. 5 also shows that interactions between humus or animals groups and depth varied. For humus components, the contrast between $U$ and $E$ is highest at the 1 and $2 \mathrm{~cm}$ depth. For fauna, the contrast between $U$ and $E$ was greatest for habitats below $3 \mathrm{~cm}$.
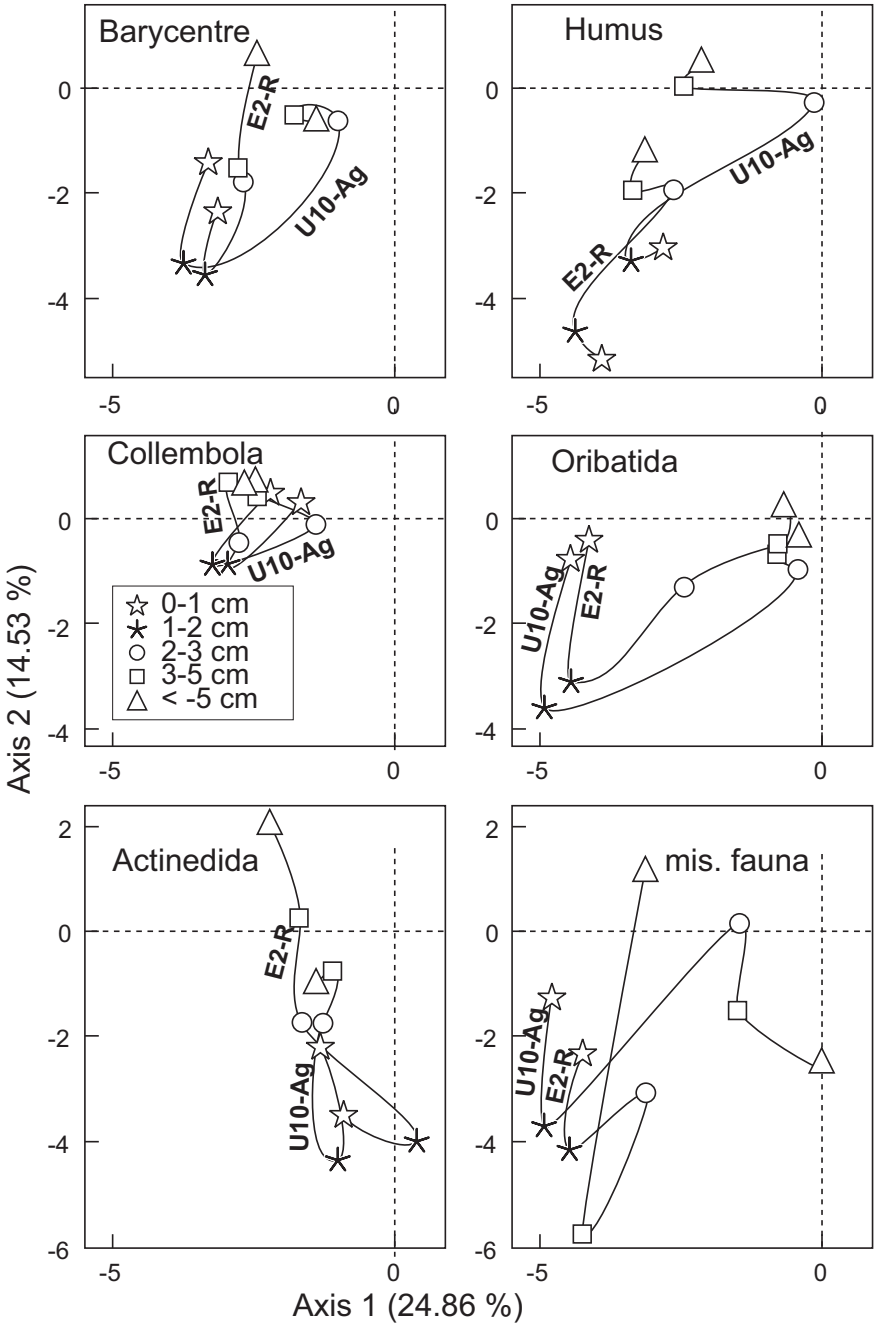

Fig. 4. Comparison of depth differentiation of Rubus habitat (E2-R) and Agrostis habitat (U10-Ag) in the two first axes of HMFA.

Animal taxa distribution showed two different trends. Animal taxa may be exclusive of a given habitat regardless of depth or may vary with depth (Fig. 6). Achipteria, Mesaphorura tenuisensilata and Sciaridae larvae are examples of dysmoder specific taxa. Isotoma saltans is a moder specific taxa while Tectocepheus illustrates a mor specific taxa (except in the deepest layers). The herb side of HMFA exhibited some nearly exclusive taxa such as Oncopodura crassicornis, Malaconothrus or Chironomidae larvae. For numerous taxa, animals discern mull from other humus forms, but only in the deepest humus layers (e.g., Pauropoda, Copepoda, Tardigrada). HMFA showed differences on the mull side between humus layers (Fig. 4) and animals (Fig. 6). Near-ground humus layers were the furthest in the herb direction, but this mull branch is better characterized by deep-soil living fauna. The contrast between $U$ and $E$ parts of the forest corroborates this result. HMFA showed that mull was both characterized by its richness in minerals in upper layers and by the high level of biological activity in deeper layers. Except for the mull branch, interactions between humus form and depth were complex and mostly taxa specific. The optimum range moved toward dysmoder with increasing depth for Oppiella, but moved away from dysmoder for Phyllhermania. Several taxa, such as Ceratozetes mites, showed a complex relationship between depth and habitat. Lastly, some taxa like Enchytraeidae worms formed a curve from moder (ground level) by mor (at middle depth) to mull (below $5 \mathrm{~cm}$ depth). 

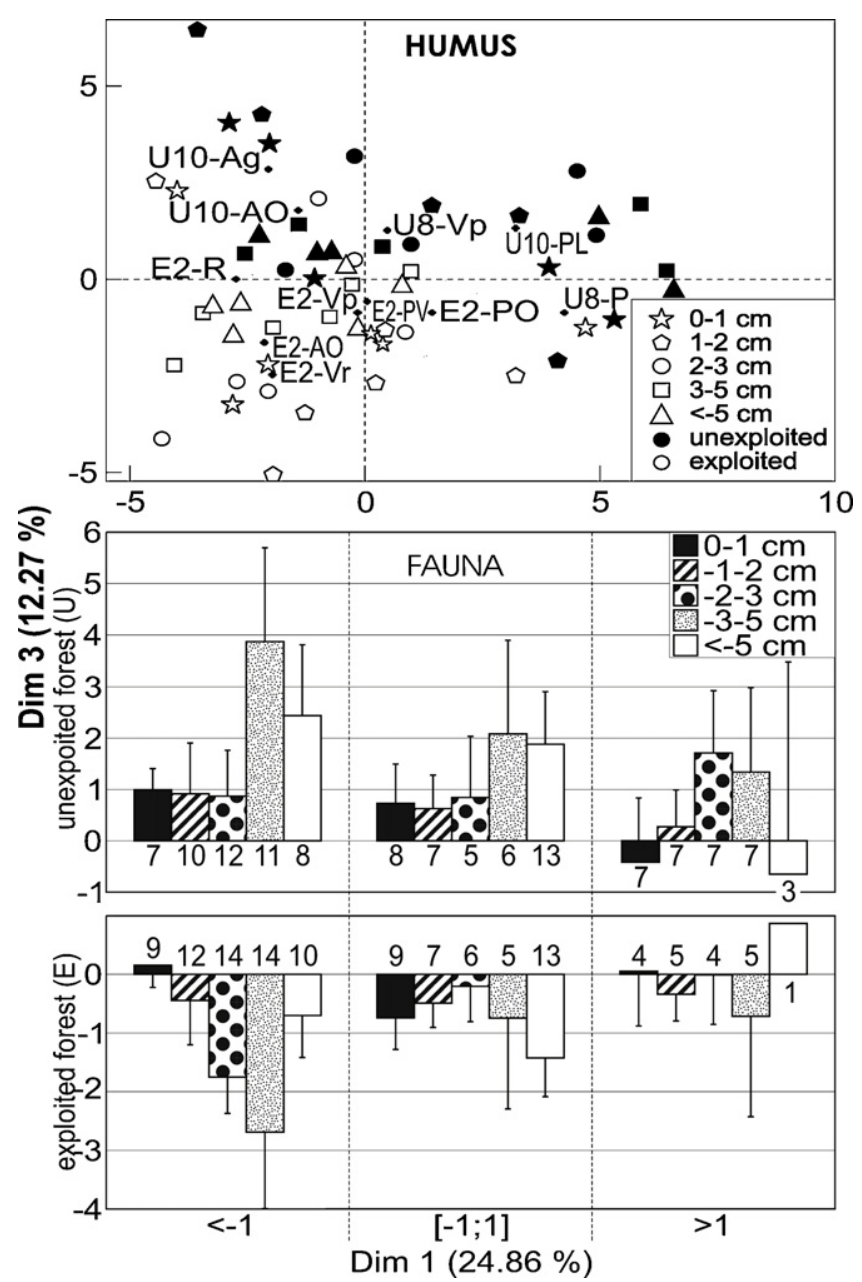

Fig. 5. Top: position of humus group in the plane of axes 1 and 3 of HMFA (same legend as Fig. 3). Bottom: mean and confidence interval of scores of the four animal groups in the third axis of HMFA grouped by first axis ( 3 classes) and forest parts (U or E). Numbers are size of each class.

\section{Discussion}

Among the various ordination methods available in the literature, MFA has rarely been used in ecology and the present study is the first application of HMFA to analyze structural relationships within complex ecological data. In contrast with frequently used multivariate methods, HMFA is concerned with both the symmetric relationship among homogeneous groups of variables and structural hierarchy among samples. This approach is motivated by the need to encompass the high number of interacting components within an ecosystem. The complexity of belowground subsystems is present in several ways such as scale, horizontal and vertical structure, diversity, and time relationships (Wardle 2002). In HMFA, variable groups provide an opportunity to be analyzed with coexisting components of the ecosystem but at individual scales or taxonomic groups. Hierarchy among sets recognizes the relative importance of the structural forces of the ecosystem such as depth gradient and spatial patterning. We demonstrate that, because of this type of resolution, HMFA simultaneously shows a broad and detailed view of interactions within an ecosystem using a low number of samples and a high number of descriptors. Indeed, given the low number of samples, our study is not adequate to study spatial heterogeneity, but our purpose was only to seek a common structure among matrices using HMFA. Combining HMFA with Fischerian methods such as spatially explicit sampling and structural equation modeling could help explain spatial structure.
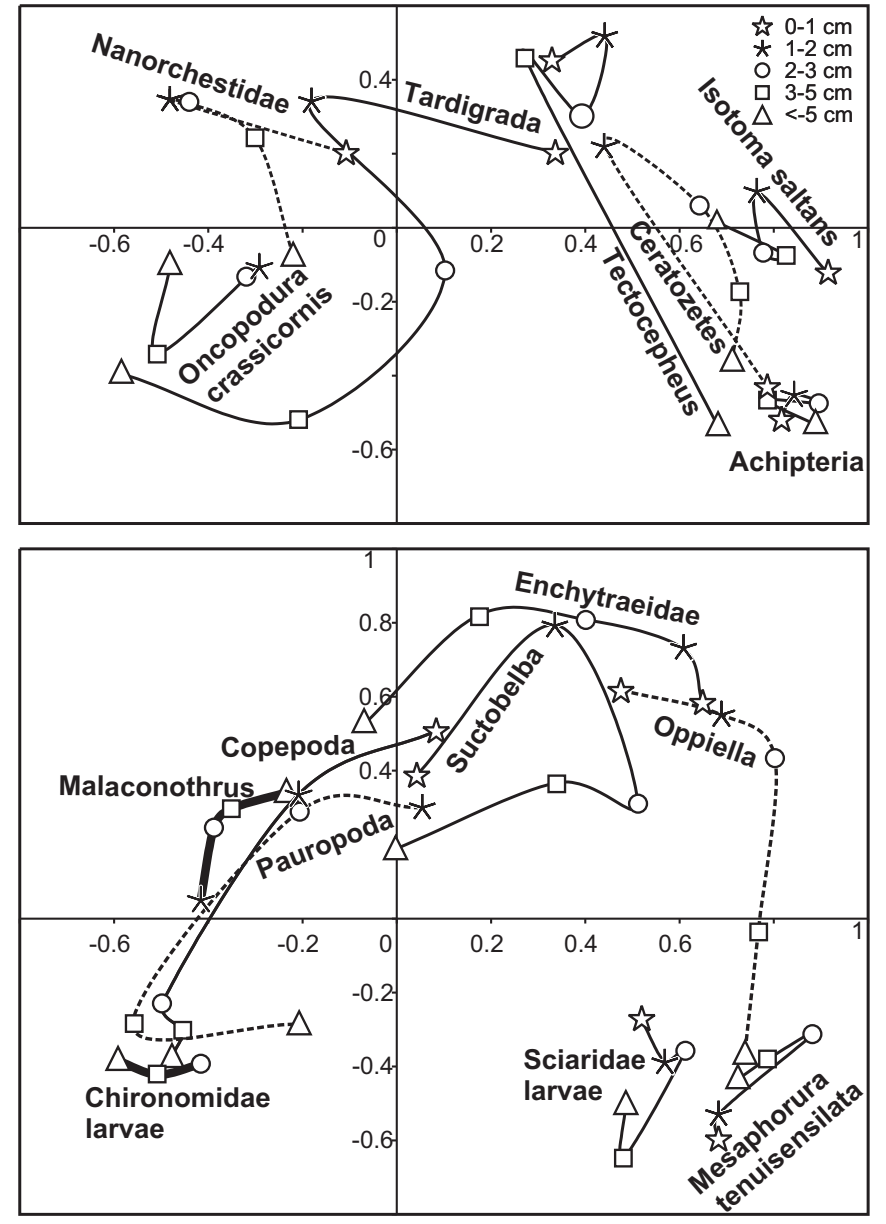

Fig. 6. Position of some animal taxa chosen among the most meaningful (cf. Appendix B) on the correlation circle to illustrate the variety of interactions with depth.

Very few studies reported such high soil animal density as we did $-3.6 \times 10^{6} \mathrm{~m}^{-2}$ (Forsslund 1948 in Ducarme et al. 2004: $2.9 \times 10^{6} \mathrm{~m}^{-2}$; Ducarme et al. 2004: $0.9 \times 10^{6} \mathrm{~m}^{-2}$ ). In agreement with Ducarme et al. (2004), we found that the density of arthropods is underrated by Berleze-Tullgren funnels, the technique used in most studies. MFA and HMFA show substantial consistency among plant community, soil fauna community and humus form that supports classical humus classification by Müller (1889), and confirmed by Hartmann (1944), Kubiena (1953), Klinka et al. (1981), Bernier and Ponge (1994) and Ponge (2003), namely, mull, moder and mor. For both plants and soil animals, mor humus does not represent the traditionally-held "extreme" humus form beyond moder, instead as suggested by Ponge et al. (2000), the "extreme" beyond moder is dysmoder. Although HMFA lends support to the mull-moder-mor model, our study also shows that plant-soil interactions are not as strong as expected compared to soil-soil interactions. Plant-soil interactions are even weaker when the soil component in question is deep. In addition, no evidence for plant-animal interaction was found (see RV coefficients, Table 1). The inconsistency between plant communities and humus habitats found in this study may be explained by the short-term variability of plant cover compared to belowground processes. The contrast that HMFA found between herb and spruce humus forms supports Ponge's (2003) point of view concerning "the pattern (strategies) for capture and use of resources by ecosystems". The richness in secondary metabolites (e.g., lignin, tannins, terpenes) is tightly linked to the life span of a plant or organ (Grime et al. 1997; Grime 
1998; Aerts 1999; Aerts and Chapin 2000; Preston and Trofymow 2000). Mull is the habitat for a high number of plant species that are short-lived such as individuals or organs either present alive or as debris (Appel 1993; Schimel et al. 1996; Aerts and Chapin 2000). A consequence of the softness and high palatability of herb tissues is the high mineralization rate and the rapid incorporation of the humified fraction within hemiorganic casts (via earthworm or Enchytraeidae). Herbs and broadleaved trees produce an "improvable" litter (Fassnacht and Gower 1999; Preston and Trofymow 2000) and the humus form is typically a mull. In contrast, plant species (or organs) with extended turnover time such as spruce, accumulate secondary metabolites in their tissues (Aerts 1997) and produce a "detrimental" litter and a moder or dysmoder humus form. Rate and richness in plant secondary metabolites rather than plant diversity drives underground processes (De Bruyne et al. 1999). Single-species plant litter is able to support a food web as complex as mixed litter, which does not support the idea of an additive effect of litter on soil biodiversity (Hansen and Coleman 1998; Ball et al. 2009). Confirming the review by Schneider et al. (2004), we notice that Oribatida promoted in spruce litter are mostly primary decomposers (e.g., Adoristes, Liacarus, Achipteria, Carabodes, Hoplophthyracarus). In contrast, herbs promote habitants belonging to the organo-mineral food web such as Tardigrada, Copepoda, and Pauropoda that mostly feed on microfauna and bacteria. Despite observations by Ducarme et al. (2004) that in forest ecosystems few taxa are exclusive to mineral horizons, mull habitat is not species poor. We hypothesize that animals are frequently enclosed within hemiorganic microporosity in mull humus, their extraction efficiency using Berleze-Tullgren method is lower compared to animals extracted from moder or mor humus types. This ultimately results in distortion.

In contrast to previous studies (Ponge 1993; Sadaka and Ponge 2003) and probably because of hierarchy, HMFA did not devote an axis to depth gradient. Nevertheless, careful examination of results shows that depth is a key criterion in distinguishing among humus forms (axis 1 and 2) and in understanding the factors involved in differentiating between exploited and preserved part of the forest. Indeed, HMFA is not a tool to describe the vertical structure of a single humus profile. Using U10Pl as an example, HMFA considered, with a limited distinction of depths, that OL, $\mathrm{OF}, \mathrm{OH}$ and $\mathrm{OA}$ layers are characteristic of eumoder irrespective of the difference between layers and sharpness of transitions. However, at closer investigation, the relative rightward position of the $2-3 \mathrm{~cm}$ depth layer (see U10Pl humus profile, Fig. 3) highlights that the OF layer exhibits a higher diagnostic value. Regarding this result, HMFA supports findings of Green et al. (1993) who proposed the OF layer as a major diagnostic layer for moder because it is the place of litter transformation into animal fecal pellets. The diagnostic ability of HMFA may be refined focusing on one among the multiple factor of the analysis. For example, dysmoder litter (U8P) is specific in terms of both habitat and inhabitants except for Actinedida that partially shared populations with mull humus forms. With respect to mull humus forms, we suggest that diagnostic horizons could distinguish between habitats (the 1-2 cm layers) and inhabitants (the $3-5 \mathrm{~cm}$ layers for most of them) (Figs. 4-6). The discrepancy between fauna and humus groups indicates that the deepest humus layers were only minimally described.

Ponge et al. (2002) put forward a one-dimensional index to assess humus biological activity: the humus index. It focuses on the mull-moder contrast only. The mor humus form was discarded from this dichotomous perspective. In our study, we foresee numerous connections between the three humus forms. Thus, mor humus form is not a "dead-end." HMFA showed that few soil fauna taxa are exclusively confined to a single humus form: most taxa are involved in several humus forms. The distinction between humus forms applies mostly in the vertical amplitude of habitat. For example, Enchytraeidae worms are abundant in moder humus but most are near the surface; they are restricted to the middle depths in mor humus and only thrive in the lower depths of mull humus. Changes in humus form may bring both modification of habitat and in the food regime for a given taxa as confirmed by feces composition. Those modifications may or not be species specific.

Our study documents that the mull-moder-mor strategies of ecosystem may coexist at the small scale. A similar small-scale pattern was already found in mountain and subalpine forests (Bernier and Ponge 1994; Sagot et al. 1999) and also to a lesser extent in temperate forests (Ponge and Delhaye 1995; Aubert et al. 2006; Chauvat et al. 2007). We confirm the finding of Kallimanis et al. (2002), which shows that forest regional biodiversity stems largely from mechanisms of patch coexistence. Our results suggest that a high proportion of below- and above-ground diversity may depend on the variability of humus conditions within a forest mosaic $(51.7 \%$ of the variance in our study) compared either to the variability below a single $25 \mathrm{~cm}^{2}$ soil area (Giller 1996) or to the variability between two forests one kilometer away. Given its fine-scale structure, local diversity must be reallocated in the course of forest development (Christensen and Emborg 1996; Dufour et al. 2006). Our study strongly suggests that habitats are more continuous than expected for many animal taxa despite contrasting humus forms. Immigration-emigration fluxes among elements of the forest mosaic (Bernier and Ponge 1994; Bernier 1996; Ponge et al. 1998; Meiners et al. 2004) could still be key processes but this all-or-nothing perspective is likely neither the only nor the most frequent response in the face of forest dynamics.

In conclusion, HMFA demonstrates strong structural relationships between the six forest floor components investigated in this study. However, this result, supported by a small-size sample, now needs to be confirmed considering forest variability. HMFA did not show direct interactions between plant and soil fauna. However, paradoxically, HMFA also supported conclusions made by Wardle (2002) that indirect plant-fauna interactions are at the focal point of the ecosystem strategy that leads to the differentiation of ecological niches within the forest mosaic. Although limited, our analysis supports that among determinisms, humus form is central. Soil animals are known to be crucial for humus profile build-up, feeding either on litter and excreting hemiorganic fecal pellets (epigeic fauna) or feeding on soil and excreting mineral fecal pellets (endogeic fauna) (Zachariae 1965; Bernier and Ponge 1994). Vegetation also controls the humus form and the soil fauna via litter deposition and root absorption and exudation (Handley 1954; Northup et al. 1995; Hobbie 2000). Moreover, plants produce secondary metabolites (Robbins et al. 1987; Appel 1993) or shorten their biological cycle (Grime et al. 1997) to face interspecific competition or herbivory. In addition, soil animals have to cope with such an aggressive phytochemical environment (Provenza et al. 2003). The key question is whether or not the same set of molecules (i.e., the products of the secondary plant metabolism) governs plant-plant, plant-fauna and also fauna-fauna interactions (Ponge et al. 1998). Our work suggests that humus form may be at the center of all theses interactions as suspected by Ponge (2003). Consequently, humus form is a key component of the ecosystem and should be considered to a greater extent in future studies on the fundamentals of diversity.

\section{Acknowledgments}

We thank Sylvaine Camaret for her help in vegetation sampling and Jean-François Ponge for his comments and critical review of the manuscript. This work was supported by the French National Forest Office (ONF) in the context of a GIP-ECOFOR project. 
Appendix A. Floristic composition of the sampled sites and correlations between MFA axes (i.e., all humus layers together) and species or supplementary variables (only correlations farthest from the axis origin are shown). Dominance codes are given according to Braun-Blanquet's scale. All data are active in MFA with all humus layers together, except plant species richness and Shannon diversity.

\begin{tabular}{|c|c|c|c|c|c|c|c|c|c|c|c|c|c|c|c|c|}
\hline & \multicolumn{11}{|c|}{ Dominance code } & \multicolumn{5}{|c|}{ Correlation $(\times 10)$} \\
\hline & U8-P & E2-PO & U10-PL & E2-PV & $\mathrm{E} 2-\mathrm{AO}$ & U8-Vp & E2-Vp & $\mathrm{E} 2-\mathrm{Vr}$ & U10-Ag & U10-AO & $\overline{E 2-R}$ & $\begin{array}{l}\text { Spruce } \\
\text { (axis 1+) }\end{array}$ & $\begin{array}{l}\text { Herb } \\
\text { (axis 1-) }\end{array}$ & $\begin{array}{l}\text { Heath } \\
\text { (axis 3+) }\end{array}$ & $\begin{array}{l}\text { Exploited } \\
\text { (axis 2-) }\end{array}$ & $\begin{array}{l}\text { Unmanaged } \\
\text { (axis 2+) }\end{array}$ \\
\hline Abies alba & + & & + & + & + & & & 1 & & & & & & & 5 & \\
\hline Acer pseudoplatanus & & & + & + & 4 & & & & & 4 & & & 4 & & & \\
\hline Adenostyles alliariae & & + & & + & & & & & & & & & & & & \\
\hline Agrostis schraderiana & & & 1 & & & & & & 5 & & & & & 4 & & 7 \\
\hline Ajuga reptans & & & & + & 2 & & & + & & 2 & 1 & & 5 & & & \\
\hline Anthoxanthum odoratum & & & & & + & & & 1 & & + & 1 & & 5 & & 3 & \\
\hline Athyrium filix-femina & & & & & & & + & + & & 2 & 4 & & 4 & & & 3 \\
\hline Blechnum spicant & & + & + & + & & + & & & & & & & & & & \\
\hline Calamintha grandiflora & & + & & & & & & & 1 & + & & & & & & 6 \\
\hline Campanula rhomboidalis & & + & & + & 1 & & & + & & & + & & 4 & & & \\
\hline Deschampsia flexuosa & & 1 & 2 & 1 & 1 & 2 & 1 & 1 & & & 1 & & & 4 & 4 & \\
\hline Dryopteris carthusiana & & + & + & + & + & & & & & & & & & & & \\
\hline Dryopteris dilatata & & + & & & & 1 & & & & & + & & & & & \\
\hline Dryopteris filix-mas & & + & & & & & & & + & 3 & & & & & & 5 \\
\hline Epilobium angustifolium & & & & & & & 1 & 1 & 1 & & & & & 7 & & \\
\hline Fragaria vesca & & & & & + & & & + & + & & & & 4 & & & \\
\hline Galeopsis tetrahit & & & & + & + & & & & + & & + & & 4 & & & \\
\hline Gentiana purpurea & & & + & & & 2 & & & & & & & & 4 & & \\
\hline Geranium sylvaticum & & & & + & + & & & 1 & + & + & 2 & & 5 & & & \\
\hline Gymnocarpium dryopteris & & + & & + & & & & & & & + & & & & & \\
\hline Hieracium murorum & & + & + & 1 & 1 & & & 1 & & & 1 & & 6 & & 5 & \\
\hline Homogyne alpina & & & 1 & 2 & 1 & 1 & & & & & & & & & & \\
\hline Hypericum maculatum & & & & & 1 & & & + & & & 1 & & 5 & & & \\
\hline Knautia dipsacifolia & & & & & 1 & & & 1 & + & & + & & 4 & & 5 & \\
\hline Lotus corniculatus & & & & & + & & & & & & 1 & & 4 & & & \\
\hline Luzula luzulina & & & & 1 & & + & 1 & & & + & + & & & 4 & 3 & \\
\hline Luzula nivea & & + & 1 & & & + & & & + & + & & 5 & & & & 3 \\
\hline Luzula sylvatica & & + & 4 & 1 & + & 1 & & & & + & & & & & & \\
\hline Maianthemum bifolium & & & & + & + & & + & & & & + & & 4 & & 4 & \\
\hline Melampyrum sylvaticum & & & & & & + & & & & & + & & 3 & & & \\
\hline Melica nutans & & & & & + & & & & & + & + & & 6 & & & \\
\hline Oxalis acetosella & & 2 & 1 & + & 4 & & & & & 2 & 1 & & 3 & & & \\
\hline Phyteuma betonicifolium & & & + & + & & & & 1 & & & + & & & & 5 & \\
\hline Picea abies & 5 & 5 & 5 & 2 & 1 & & + & 1 & & & 1 & 6 & & & 3 & \\
\hline Prenanthes purpurea & & 3 & 2 & 2 & 2 & + & + & 1 & & + & 1 & & & & 4 & \\
\hline Ranunculus nemorosus & & & & & & & & + & & & 1 & & 4 & & & \\
\hline Ranunculus platanifolius & & 1 & & + & 1 & & & & 1 & + & 1 & & 5 & & & \\
\hline Rosa pendulina & & & & & & & & & 2 & 2 & & & & & & 8 \\
\hline Rubus fruticosus & & & & & & & 1 & & 1 & & & & & 6 & & \\
\hline Rubus idaeus & & & & & + & & 1 & + & 2 & 2 & 4 & & 4 & & & 5 \\
\hline Rumex acetosa & & + & & & + & & & & & & & & & & & \\
\hline Sorbus aucuparia & & & & + & & & & & + & & & & & & & \\
\hline Vaccinium myrtillus & + & 2 & 1 & 4 & 1 & 5 & 5 & 5 & & & 1 & & & 5 & 7 & \\
\hline Viola riviniana & & + & & + & 1 & & & & & & & & 3 & & & \\
\hline Species richness & 3 & 19 & 16 & 24 & 26 & 12 & 10 & 21 & 16 & 17 & 29 & & 6 & & & \\
\hline Shannon diversity & 1.0 & 4.1 & 5.0 & 5.6 & 7.9 & 3.3 & 2.5 & 5.6 & 4.2 & 7.2 & 8.0 & & 8 & & & \\
\hline
\end{tabular}


Appendix B. Mean fauna density and correlations between MFA (i.e., all humus layers together) and taxa or supplementary variables (only correlations farthest from the axis origin are shown). Taxa with density $<200 \mathrm{~m}^{-2}$ and detail for each sampled site are not shown. All data are active in MFA-total except total density, species richness and Shannon diversity.

\begin{tabular}{|c|c|c|c|c|c|c|c|}
\hline & \multirow{2}{*}{$\begin{array}{l}\text { Density } \\
\left(1000 \mathrm{~m}^{-2}\right)\end{array}$} & \multirow{2}{*}{$\begin{array}{l}\text { Confidence } \\
\text { interval }\end{array}$} & \multicolumn{5}{|c|}{ Correlation $(\times 10)$} \\
\hline & & & $\begin{array}{l}\text { Spruce } \\
\text { (axis 1+) }\end{array}$ & $\begin{array}{l}\text { Herb } \\
\text { (axis 1-) }\end{array}$ & $\begin{array}{l}\text { Heath } \\
\text { (axis 3+) }\end{array}$ & $\begin{array}{l}\text { Unmanaged } \\
\text { (axis 2+) }\end{array}$ & $\begin{array}{l}\text { Exploited } \\
\text { (axis 2-) }\end{array}$ \\
\hline \multicolumn{8}{|l|}{ Hexapoda, Collembola } \\
\hline Ceratophysella denticulata & 1.7 & 1.2 & & & & & 7 \\
\hline Entomobrya quinquelineata & 0.6 & 0.4 & & & 8 & & \\
\hline Folsomia sensibilis & 8.7 & 11.0 & 9 & & & & \\
\hline Friesea mirabilis & 3.1 & 6.0 & 7 & & & & \\
\hline Isotoma saltans & 8.3 & 8.8 & 8 & & & & \\
\hline Isotomiella minor & 45.3 & 21.7 & & & & 8 & \\
\hline Lepidocyrtus lanuginosus & 1.8 & 1.0 & & 7 & & 3 & \\
\hline Megalothorax minimus & 3.5 & 2.0 & & & 4 & & \\
\hline Mesaphorura hylophyla & 5.2 & 7.0 & & & & & 4 \\
\hline Mesaphorura italica & 3.6 & 4.9 & 5 & & & & 4 \\
\hline Mesaphorura macrochaeta & 15.2 & 11.3 & & & & & 7 \\
\hline Mesaphorura tenuisensilata & 21.9 & 30.8 & 8 & & & & \\
\hline Micranuridae pigmea & 2.7 & 2.2 & & & & & \\
\hline Oncopodura crassicornis & 1.1 & 1.3 & & 5 & & & 3 \\
\hline Oligaphorura absoloni & 1.5 & 2.0 & 7 & & & & \\
\hline Parisotoma notabilis & 5.4 & 2.9 & & & & 5 & \\
\hline Protaphorura cancelata & 9.3 & 6.8 & 5 & & & & \\
\hline Pseudanurophorus binoculatus & 2.1 & 1.4 & & & 3 & & \\
\hline Sminthuridae spp.1 & 0.3 & 0.4 & & & 5 & & \\
\hline Vergatopus montana & 0.8 & 1.0 & & & & 5 & \\
\hline Willemia anolphthalma & 4.3 & 4.5 & 9 & & & & \\
\hline Willemia aspinata & 1.2 & 0.9 & & & & & \\
\hline Xenylla boerneri & 0.5 & 0.9 & & & & & \\
\hline Collembola: total density & 149.3 & 81.9 & 8 & & & & \\
\hline Collembola: richness & 15.9 & 1.4 & 5 & & & & 7 \\
\hline Collembola: diversity & 6.7 & 1.4 & & & & & 8 \\
\hline \multicolumn{8}{|l|}{ Acarina, Actinedida } \\
\hline Alicorhagiidae & 18.6 & 19.0 & 8 & & & & \\
\hline Anystidae spp.1 & 0.3 & 0.3 & 5 & & & & \\
\hline Anystidae spp. 2 & 0.3 & 0.4 & & & 5 & & \\
\hline Anystidae spp. 3 & 0.7 & 1.3 & & & 3 & 6 & \\
\hline Bimichaeliidae & 2.9 & 1.7 & 5 & & & & 4 \\
\hline Ereynetidae & 0.3 & 0.2 & & & & & \\
\hline Eupodidae spp.1 & 6.2 & 3.6 & 9 & & & & \\
\hline Eupodidae spp.2 & 0.3 & 0.3 & & & 5 & 5 & \\
\hline Eupodidae spp. 3 & 4.3 & 2.9 & 5 & & & & \\
\hline Nanorchestidae & 5.7 & 3.8 & & 5 & & & 5 \\
\hline Rhagidiidae spp.1 & 7.2 & 5.2 & 10 & & & & \\
\hline Rhagidiidae spp.2 & 4.0 & 3.1 & 9 & & & & \\
\hline Scutacaridae & 0.9 & 0.8 & & & & & \\
\hline Tarsonemidae & 0.2 & 0.3 & & 3 & & 5 & \\
\hline Tetranychidae & 1.0 & 1.0 & & & 5 & 6 & \\
\hline Tydeidae spp.1 & 16.1 & 21.1 & 6 & & & & 4 \\
\hline Tydeidae spp.2 & 5.1 & 3.3 & & & & 7 & \\
\hline Tydeidae spp.3 & 0.7 & 0.6 & & & & & \\
\hline Tydeidae spp.4 & 0.3 & 0.4 & & & 6 & & \\
\hline Tydeidae spp.5 & 13.1 & 17.4 & 6 & & & & 5 \\
\hline Actinedida: total density & 89.3 & 67.2 & 9 & & & & \\
\hline Actinedida: richness & 13.9 & 1.6 & & & 4 & & 5 \\
\hline Actinedida: diversity & 7.9 & 1.2 & & & 5 & & 4 \\
\hline \multicolumn{8}{|l|}{ Acarina, Oribatida } \\
\hline Adoristes & 0.5 & 0.6 & 5 & & & & \\
\hline Achipteria & 10.8 & 13.3 & 8 & & & 3 & \\
\hline Atopochthonius & 0.7 & 1.0 & & & 4 & & 6 \\
\hline Austrocarabodes & 0.3 & 0.4 & & & & & 3 \\
\hline Autogneta & 1.4 & 2.1 & & & 5 & & \\
\hline Carabodes spp.1 & 12.3 & 9.9 & 9 & & & & \\
\hline Ceratozetella & 0.3 & 0.4 & & 3 & & 8 & \\
\hline Ceratozetes & 18.1 & 24.4 & 8 & & & & \\
\hline Chamobates & 9.1 & 6.9 & 8 & & 3 & 3 & \\
\hline Ctenobelba & 1.9 & 2.1 & & & & & 5 \\
\hline Cymbaeremaeus & 0.7 & 0.4 & 7 & & & 5 & \\
\hline Epidamaeus & 0.4 & 0.4 & 9 & & & & \\
\hline Eulohmannia spp.2 & 1.6 & 1.4 & & 3 & 6 & & 5 \\
\hline Eupelops & 0.3 & 0.2 & & & & 5 & \\
\hline
\end{tabular}


Appendix B (Continued)

\begin{tabular}{|c|c|c|c|c|c|c|c|}
\hline & \multirow{2}{*}{$\begin{array}{l}\text { Density } \\
\left(1000 \mathrm{~m}^{-2}\right)\end{array}$} & \multirow{2}{*}{$\begin{array}{l}\text { Confidence } \\
\text { interval }\end{array}$} & \multicolumn{5}{|c|}{ Correlation $(\times 10)$} \\
\hline & & & $\begin{array}{l}\text { Spruce } \\
\text { (axis 1+) }\end{array}$ & $\begin{array}{l}\text { Herb } \\
\text { (axis 1-) }\end{array}$ & $\begin{array}{l}\text { Heath } \\
\text { (axis 3+) }\end{array}$ & $\begin{array}{l}\text { Unmanaged } \\
\text { (axis } 2+\text { ) }\end{array}$ & $\begin{array}{l}\text { Exploited } \\
\text { (axis 2-) }\end{array}$ \\
\hline Hoplophthiracarus & 0.8 & 0.5 & 7 & & & & \\
\hline Liacarus & 1.9 & 2.0 & 9 & & & & \\
\hline Malaconothrus & 26.0 & 33.6 & & 3 & 4 & & 6 \\
\hline Melanozetes & 0.4 & 0.8 & & & & & \\
\hline Nanhermannia & 8.8 & 17.0 & & & & & \\
\hline Neomycobates spp.1 & 1.0 & 1.1 & & & 4 & & \\
\hline Oppiella & 121.3 & 136.1 & 9 & & & & \\
\hline Oribatula spp.2 & 0.4 & 0.5 & & & & 5 & \\
\hline Oribella & 0.7 & 1.2 & & & & 6 & \\
\hline Palaeacarus & 0.7 & 0.4 & & 7 & & & \\
\hline Phyllhermannia & 6.7 & 8.9 & & & & & \\
\hline Platynothrus & 1.2 & 1.5 & & 4 & & & 5 \\
\hline Quadroppia & 2.0 & 2.0 & & & & & \\
\hline Suctobelba & 11.9 & 6.1 & & & 5 & 6 & \\
\hline Tectocepheus & 12.3 & 9.8 & & & 5 & 3 & \\
\hline Zygoribatula & 0.3 & 0.5 & & & & & \\
\hline Larvae & 331.1 & 250.9 & 7 & & & & 3 \\
\hline Oribatida: total density & 587.0 & 410.7 & 8 & & & & \\
\hline Oribatida: richness & 17.6 & 1.4 & & & 8 & & \\
\hline Oribatida: diversity & 6.1 & 1.4 & & 6 & & 7 & \\
\hline \multicolumn{8}{|l|}{ Acarina Acaridida } \\
\hline Acaridae spp.1 & 1.0 & 0.9 & & 3 & & & \\
\hline Acaridae spp. 2 & 0.7 & 0.3 & & & & & \\
\hline Acaridae spp.3 & 0.6 & 0.5 & & & & & 6 \\
\hline \multicolumn{8}{|l|}{ Acarina Gamasida } \\
\hline Gamasina & 22.3 & 10.4 & 7 & & & 6 & \\
\hline Miscellaneous & 5.5 & 1.5 & & & & 8 & \\
\hline Uropodina & 0.3 & 0.3 & & & & 4 & \\
\hline \multicolumn{8}{|l|}{ Myriapoda } \\
\hline Diplopoda & 0.3 & 0.3 & & & & 6 & \\
\hline Pauropoda & 9.0 & 4.2 & & & & & \\
\hline Symphyla & 2.3 & 2.2 & & 4 & & & 4 \\
\hline \multicolumn{8}{|l|}{ Diptera (larvae) } \\
\hline Cecidomyiidae & 2.3 & 1.8 & 6 & & & & \\
\hline Chironomidae & 1.0 & 1.3 & & 5 & & & \\
\hline Empididae & 0.5 & 0.5 & 5 & & & & \\
\hline Sciaridae & 5.5 & 5.8 & 6 & & & & 4 \\
\hline Miscellaneous & 0.5 & 0.2 & & & & 4 & \\
\hline Araneae & 0.3 & 0.2 & 5 & & 3 & 4 & \\
\hline Crustacea, Copepoda & 3.7 & 4.5 & & 3 & & 7 & \\
\hline Hexapoda, Diplura & 1.1 & 1.3 & 7 & & & & 4 \\
\hline Hexapoda, Protura & 32.7 & 19.4 & 7 & & & & \\
\hline Olichochaeta, Enchytraeidae & 103.9 & 46.6 & & & 8 & & \\
\hline Olichochaeta, Lombricidae & 0.5 & 0.5 & & & & & 3 \\
\hline Platyhelpinthes, Turbellaria & 0.6 & 0.6 & & & & 4 & \\
\hline Tardigrada & 12.0 & 9.2 & & 5 & & & \\
\hline \multicolumn{8}{|l|}{ Insecta } \\
\hline Coleoptera (larvae) & 0.9 & 0.4 & 5 & & & & \\
\hline Homoptera (aphids) & 10.8 & 7.7 & 6 & & & 5 & \\
\hline Thysanoptera & 0.3 & 0.2 & & & 5 & & \\
\hline Diptera (imago) & 1.0 & 0.6 & 6 & & & & \\
\hline Fauna: total density & 1050.3 & 564.8 & 9 & & & & \\
\hline Fauna: supra-family richness & 22.3 & 2.1 & & & & & 5 \\
\hline Fauna: supra-family diversity & 5.5 & 1.1 & & 6 & & 5 & \\
\hline
\end{tabular}


Appendix C. Humus composition of the sampled sites (\% in volume), supplementary variables and correlations with MFA axes (i.e., all humus layers together). Only correlations farthest from the axis origin are shown. All data are active in MFA except *

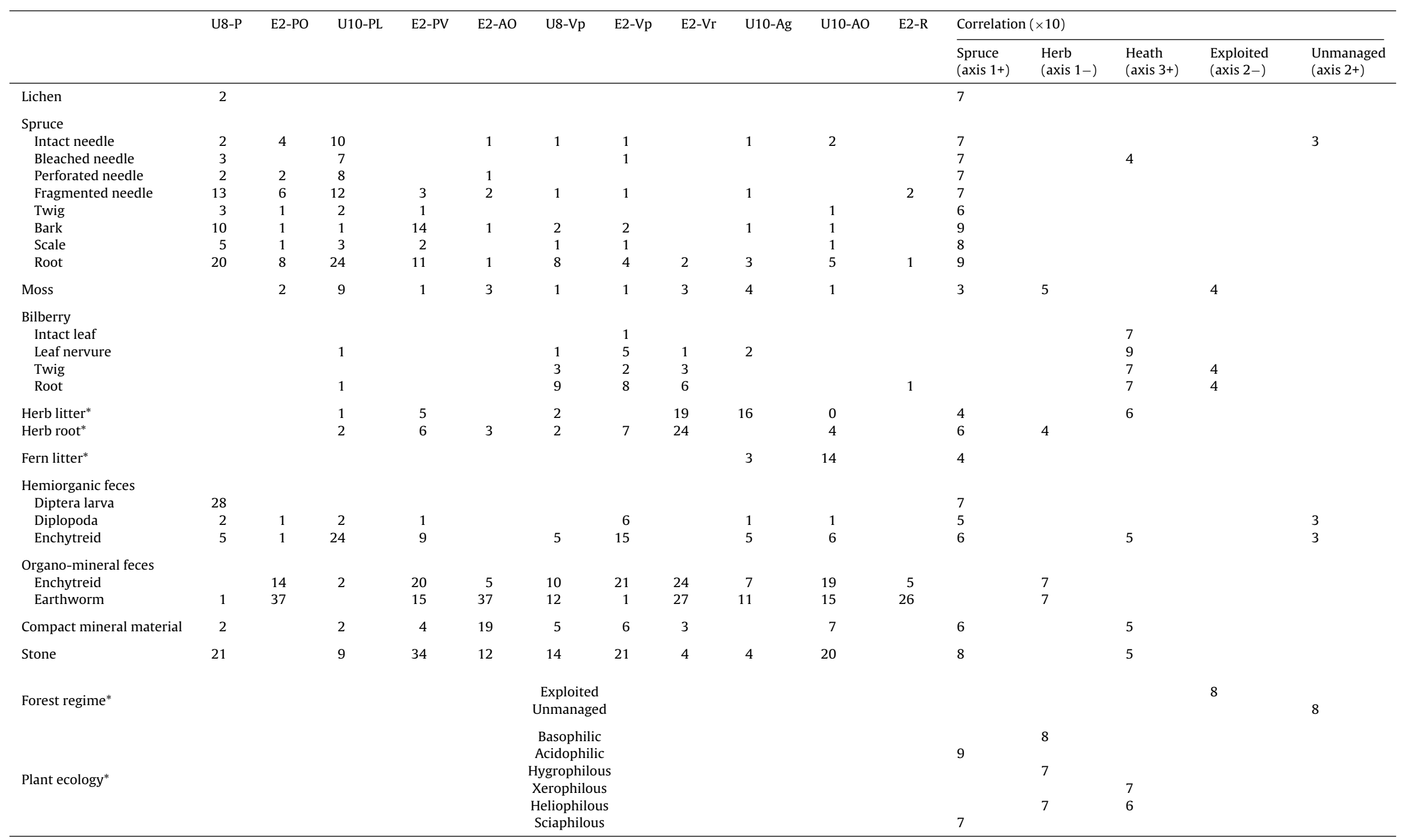




\section{References}

Aerts, R., 1997. Climate, leaf litter chemistry and leaf litter decomposition in terrestrial ecosystems: a triangular relationship. Oikos 79, 439-449.

Aerts, R., 1999. Interspecific competition in natural plant communities: mechanisms, trade-offs and plant-soil feedbacks. Journal of Experimental Botany 50, 29-37.

Aerts, R., Chapin, F.S., 2000. The mineral nutrition of wild plants revisited: a reevaluation of processes and patterns. Advances in Ecological Research 30, $1-67$.

Aeschimann, D., Lauber, K., Moser, D.M., Theurillat, J.P., 2004. Flora alpina. Belin, Paris.

Appel, H.M., 1993. Phenolics in ecological interactions: the importance of oxidation. Journal of Chemical Ecology 19, 1521-1552.

Aubert, M., Margerie, P., Ernoult, A., Decaëns, T., Bureau, F., 2006. Variability and heterogeneity of humus forms at stand level: comparison between pure beech and mixed beech-hornbeam forest. Annals of Forest Science 63, 177-188.

Baize, D., Girard, M.C., AFES, 2009. Référentiel pédologique. Quae, Paris.

Ball, B.A., Bradford, M.A., Coleman, D.C., Hunter, M.D., 2009. Linkages between below and aboveground communities: decomposer responses to simulated tree species loss are largely additive. Soil Biology and Biochemistry 41, 1155-1163.

Bardgett, R.D., Cook, R., 1998. Functional aspects of soil animal diversity in agricultural grasslands. Applied Soil Ecology 10, 263-276.

Barkman, J.J., 1978. Synusial approaches to classification. In: Whittaker, R.H. (Ed.), Classification of Plant Communities. Junk. Robert Harding, The Hague, pp. 111-165.

Beare, M.H., Coleman, D.C., Crossley Jr., D.A., Hendrix, P.F., Odum, E.P., 1995. A hierarchical approach to evaluating the significance of soil biodiversity to biochemical cycling. In: Collins, H.P., Robertson, G.P., Klug, M.J. (Eds.), The Significance and Regulation of Soil Biodiversity. Kluwer Academic Publishers, Dordrecht, pp. $5-22$.

Berg, M.P., Kniese, J.P., Bedaux, J.J.M., Verhoef, H.A., 1998. Dynamics and stratification of functional groups of micro- and mesoarthropods in the organic layer of a Scots pine forest. Biology and Fertility of Soils 26, 268-284.

Bernier, N., 1996. Altitudinal changes in humus form dynamics in a spruce forest at the montane level. Plant and Soil 178, 1-28.

Bernier, N., Ponge, J.F., 1994. Humus form dynamics during the sylvogenetic cycle in a mountain spruce forest. Soil Biology and Biochemistry 26, $183-220$.

Borcard, D., Gillet, F., Legendre, P., 2011. Numerical Ecology with R. Springer, Use R! series, New York.

Chauvat, M., Ponge, J.F., Wolters, V., 2007. Humus structure during a spruce forest rotation: quantitative changes and relationship to soil biota. European Journal of Soil Science 58, 625-631.

Christensen, M., Emborg, J., 1996. Biodiversity in natural versus managed forest in Denmark. Forest Ecology and Management 85, 47-51.

Coleman, D.C., Whiteman, W.B., 2005. Linking species richness, biodiversity and ecosystem function in soil systems. Pedobiologia 49, 479-497.

Crow, S.E., Filley, T.R., McCormick, M., Szlavecz, K., Stott, D.E., Gamblin, D., Conyers, G., 2009. Earthworms, stand age, and species composition interact to influence particulate organic matter chemistry during forest succession. Biogeochemistry 92, 61-82.

De Bruyne, T., Pieters, L., Deelstra, H., Vlietinck, A., 1999. Condensed vegetable tannins: biodiversity in structure and biological activities. Biochemical Systematics and Ecology 27, 445-459.

De Deyn, G.B., Raaijmakers, C.E., Zoomer, H.R., Berg, M.P., de Ruiter, P.C., Verhoef, H.A., Bezemer, T.M., van der Putten, W.H., 2003. Soil invertebrate fauna enhances grassland succession and diversity. Nature 422, 711-714.

Doblas-Miranda, E., Sanchez-Pinero, F., Gonzalez-Medias, A., 2009. Different microhabiats affect soil macroinvertebrate assemblages in a mediterranean arid ecosystem. Applied Soil Ecology 41, 329-335.

Dray, S., Chessel, D., Thioulouse, J., 2003. Co-inertia analysis and the linking of ecological data tables. Ecology 84, 3078-3089.

Ducarme, X., André, H.M., Wauthy, G., Lebrun, P., 2004. Are there real endogeic species in temperate forest mites? Pedobiologia 48, 139-147.

Dufour, A., Gadallah, F., Wagner, H.H., Guisan, A., Buttler, A., 2006. Plant species richness and environmental heterogeneity in a mountain landscape: effects of variability and spatial configuration. Ecography 29, 573-584.

Escofier, B., Pagès, J., 1994. Multiple factor analysis (AFMULT package). Computational Statistics \& Data Analysis 18, 121-140.

Fassnacht, K.S., Gower, S.T., 1999. Comparison of the litterfall and forest floor organic matter and nitrogen dynamics of upland forest ecosystems in north central Wisconsin. Biogeochemistry 45, 265-284.

Giller, P.S., 1996. The diversity of soil communities, the "poor man's tropical rainforest". Biodiversity and Conservation 5, 135-168.

Gillet, F., Gallandat, J.D., 1996. Integrated synusial phytosociology: some notes on a new, multiscalar approach to vegetation analysis. Journal of Vegetable Science 7, 13-18.

Green, R.N., Trowbridge, R.L., Klinka, K., 1993. Towards a taxonomic classification of humus forms. Forest Science Monographs 29, 1-49.
Grime, J.P., 1998. Benefits of plant diversity to ecosystems: immediate, filter and founder effects. Journal of Ecology 86, 902-910.

Grime, J.P., Thompson, K., Hunt, R., Hodgson, J.G., Cornelissen, J.H.C., Rorison, I.H., Hendry, G.A.F., Ashenden, T.W., Askew, A.P., Band, S.R., Booth, R.E., Bosssard, C.C., Campbell, B.D., Cooper, J.E.L., Davison, A.W., Gupta, P.L., Hall, W., Hand, D.W., Hannah, M.A., Hillier, S.H., Hodkinson, D.J., Jalili, A., Liu, Z., Mackey, J.M.L., Matthews, N., Mowforth, M.A., Neal, A.M., Reader, R.J., Reiling, K., Ross-Fraser, W., Spencer, R.E., Sutton, F., Tasker, D.E., Thorpe, P.C., Whitehouse, J., 1997. Integrated screening validates primary axes of specialisation in plants. Oikos 79, 259-281.

Handley, W.R.C., 1954. Mull and mor formation in relation to forest soil. Forestry Commission, Bulletin no. 23, London.

Hansen, R.A., Coleman, D.C., 1998. Litter complexity and composition are determinants of the diversity and species composition of oribatid mites (Acari: Oribatida) in litterbags. Applied Soil Ecology 9, 17-23.

Hartmann, F., 1944. Waldhumusformen. Zeitschrift für das Gesamte Forstwesen 76, 39-71.

Hobbie, S.E., 2000. Interactions between litter lignin and soil nitrogen availability during leaf litter decomposition in a Hawaiian Montane forest. Ecosystems 3, 484-494.

Hooper, D.U., Bignell, D.E., Brown, V.K., Brussaard, L., Dangerfield, J.M., Wall, D.H., Wardle, D.A., Coleman, D.C., Giller, K.E., Lavelle, P., Van der Putten, W.H., de Ruiter, P.C., Rusek, J., Silver, W.L., Tiedje, J.M., Wolters, V., 2000. Interactions between aboveground and belowground biodiversity in terrestrial ecosystems: patterns, mechanisms, and feedbacks. Bioscience 50, 1049-1061.

Husson, F., Josse, J., Lê, S., Mazet, J., 2009. FactoMineR: Factor Analysis and Data Mining with R. R Package Version 1.12., http://CRAN.Rproject.org/package=FactoMineR.

Huston, M.A., 1999. Local processes and regional patterns: appropriate scales for understanding variation in the diversity of plant and animals. Oikos 86, 393-401.

IUSS Working Group, 2006. World Reference Base for Soil Resources, 2006: A Framework for International Classification, Correlation and Communication. World Soil Resources Rep. No. 103, Rome.

Josse, J., Pagès, J., Husson, F., 2008. Testing the significance of the RV coefficient. Computational Statistics \& Data Analysis 53, 82-91.

Kallimanis, A.S., Argyropoulou, M.D., Sgardelis, S.P., 2002. Two scale patterns of spatial distribution of oribatid mites (Acari, Cryptostigmata) in a Greek mountain. Pedobiologia 46, 513-525.

Kareiva, P., 1994. Diversity begets productivity. Nature 368, 686-687.

King, R.F., Dromph, K.M., Bardgett, R.D., 2002. Changes in species evenness of litter have no effect on decomposition processes. Soil Biology and Biochemistry 34, 1959-1963.

Klinka, K., Green, R.N., Trowbridge, R.L., Lowe, L.E., 1981. Taxonomic Classification of Humus Forms in Ecosystems of British Columbia. First Approximation. Ministry of Forests, Province of British Columbia.

Kubiena, W.L., 1953. The Soils of Europe. Thomas Murby \& Co., London.

Laganière, J., Paré, D., Bradley, R.L., 2009. Linking the abundance of aspen with soil faunal communities and rates of belowground processes within single stands of mixed aspen-black spruce. Applied Soil Ecology 41, 19-28.

Lavelle, P., Blanchart, E., Martin, A., Martin, S., Spain, A.V., Toutain, F., Barois, I., Schaefer, R., 1993. A hierarchical model for decomposition in terrestrial ecosystems: application to soil of the humid tropics. Biotropica 25, 130-150.

Lê, S., Josse, J., Husson, F., 2008. FactoMineR: an R package for multivariate analysis. Journal of Statistical Software 25, 1-18.

Le Dien, S., Pagès, J., 2003. Analyse factorielle multiple hiérarchique. Revue de Statistique Appliquée 51, 47-73.

Legendre, P., Gallagher, E.D., 2001. Ecologically meaningful transformations for ordination of species data. Oecologia 129, 271-280.

Loreau, M., 2000. Are communities saturated? On the relationship between alpha, beta and gamma diversity. Ecology Letters 3, 73-76.

Marra, J.L., Edmonds, R.L., 2005. Soil arthropod responses to different patch types in a mixed-conifer forest of the Sierra Nevada. Forest Science 51, 255-265.

Mathieu, J., Grimaldi, M., Jouquet, P., Rouland, C., Lavelle, P., Desjardins, T., Rossi, J.P., 2009. Spatial patterns of grasses influence soil macrofauna biodiversity in Amazonian pastures. Soil Biology and Biochemistry 41, 586-593.

Meiners, S.J., Cadenasso, M.L., Pickett, S.T.A., 2004. Beyond biodiversity: individualistic controls of invasion in a self-assembled community. Ecology Letters 7, 121-126.

Müller, P.E., 1889. Recherches sur les formes naturelles de l'humus et leur influence sur la végétation et le sol. Berger-Levrault \& Co, Nancy.

Nagaike, T., Kamitani, T., Nakashizuka, T., 1999. The effect of shelterwood logging on the diversity of plant species in a beech (Fagus crenata) forest in Japan. Forest Ecology and Management 118, 161-171.

Northup, R.R., Zengshou, Y., Dahlgren, R.A., Vogt, K.A., 1995. Polyphenol control of nitrogen release from pine litter. Nature 377, 227-229.

Ponge, J.F., 1984. Etude écologique d'un humus forestier par l'observation d'un petit volume, premiers résultats. I. - La couche L1 d'un moder sous pin sylvestre. Revue d'Ecologie et de Biologie du Sol 21, 161-187.

Ponge, J.F., 1993. Biocenoses of Collembola in atlantic temperate grass-woodland ecosystems. Pedobiologia 37, 223-244.

Ponge, J.F., 2003. Humus forms in terrestrial ecosystems: a framework to biodiversity. Soil Biology and Biochemistry 35, 935-945. 
Ponge, J.F., André, J., Zackrisson, O., Bernier, N., Nilsson, M.C., Gallet, C., 1998. The forest regeneration puzzle. Biological mechanisms in humus layer and forest vegetation dynamics. Bioscience 48, 523-530.

Ponge, J.F., Charnet, F., Allouard, J.M., 2000. Comment distinguer dysmoder et mor? L'exemple de la forêt domaniale de Perche-Trappe (Orne). Revue Forestière Française 52, 23-37.

Ponge, J.F., Chevallier, R., Loussot, P., 2002. Humus index: an integrated tool for the assessment of forest floor and topsoil properties. Soil Science Society of America Journal 66, 1996-2001.

Ponge, J.F., Delhaye, L., 1995. The heterogeneity of humus profiles and earthworm communities in a virgin beech forest. Biology and Fertility of Soils 20, 24-32.

Porazinska, D.L., Bardgett, R.D., Blaauw, M.B., Hunt, H.W., Parsons, A.N., Seastedt, T.R., Wall, D.H., 2003. Relationships at the aboveground-belowground interface: plants, soil biota, and soil processes. Ecological Monographs 73, 377-395.

Preston, C.M., Trofymow, J.A., 2000. Variability in litter quality and its relationship to litter decay in Canadian forests. Canadian Journal of Botany 78, 1269-1287.

Provenza, F.D., Villalba, J.J., Bryant, J.P., 2003. Linking herbivore experience, varied diets, and plant biochemical diversity. Small Ruminant Research 49, 257-274.

R Development Core Team, 2009. R: A Language and Environment for Statistical Computing. R Foundation for Statistical Computing, ISBN 3-900051-07-0, http://www.R-project.org.

Robbins, C.T., Hanley, T.A., Hagerman, A., Hjeljord, E.O., Baker, D.L., Schwartz, C.C., Mautz, W.W., 1987. Role of tannins in defending plants against ruminants: reduction in protein availability. Ecology 68, 98-107.

Robert, P., Escoufier, Y., 1976. A unifying tool for linear multivariate statistical methods: the RV-coefficient. Journal of the Royal Statistical Society Series C: Applied Statistics 25, 257-265.

Sadaka, N., Ponge, J.F., 2003. Climatic effects on soil trophic networks and the resulting humus profiles in holm oak (Quecus rotundifolia) forests in the high atlas of Morocco as revealed by correspondence analysis. European Journal of Soil Science 54, 767-777.
Sagot, C., Brun, J.J., Grossi, J.L., Chauchat, J.H., Boudin, G., 1999. Earthworm distribution and humus forms in the development of a semi-natural alpine spruce forest. European Journal of Soil Biology 35, 163-169.

Salmon, S., Frizzera, L., Camaret, S., 2008. Linking forest dynamics to richness and assemblage of soil zoological groups and to soil mineralization processes. Forest Ecology and Management 256, 1612-1623.

Scherer-Lorenzen, M., Palmborg, C., Prinz, A., Schulze, E.D., 2003. The role of plant diversity and composition for nitrate leaching in grasslands. Ecology 84 1539-1552.

Schimel, J.P., Van Cleve, K., Cates, R.G., Clausen, T.P., Reichardt, P.B., 1996. Effects of balsam poplar (Populus balsamifera) tannins and low molecular weight phenolics on microbial activity in taiga floodplain soil: implications for changes in $\mathrm{N}$ cycling during succession. Canadian Journal of Botany 74, 84-90.

Schneider, K., Renker, C., Scheu, S., Maraun, M., 2004. Feeding biology of oribatid mites: a minireview. Phytophaga 14, 247-256.

Siemann, E., Haarstad, J., Tilman, D., 1999. Dynamics of plant and arthropod diversity during old field succession. Ecography 22, 406-414.

Spehn, E.M., Joshi, J., Schmid, B., Alphei, J., Körner, C., 2000. Plant diversity effects on soil heterotrophic activity in experimental grassland ecosystems. Plant and Soil 224, 217-230.

Tilman, D., 2000. Causes, consequences and ethics of biodiversity. Nature 405 208-211.

Tilman, D., Lehman, C., Thomson, K.T., 1997. Plant diversity and ecosystem productivity: theoretical considerations. Proceedings of the National Academy of Sciences of the United States of America 94, 1857-1861.

Wardle, D.A., 1999. How soil food webs make plants grow. Trends in Ecology \& Evolution 14, 418-420.

Wardle, D., 2002. Communities and ecosystems: linking the aboveground and belowground components. Monographs in Population Biology no. 34. Prinston University Press.

Zachariae, G., 1965. Spuren tierischer Tätigkeit im Boden des Buchenwaldes. Forstwissenschaftliche Forschungen 20,1-68.

Zimmer, M., 2002. Is decomposition of woodland leaf litter influenced by its species richness? Soil Biology and Biochemistry 34, 277-284. 